\title{
Saying 'No' to Strasbourg: When Are National Parliaments Justified in Refusing to Give Effect to Judgments of International Human Rights Courts?
}

\author{
Colm O'Cinneide
}

\author{
Professor of Constitutional and Human Rights Law, UCL
}

\begin{abstract}
This paper critically analyses the normative strength of claims that national authorities - and in particular national parliaments - would be justified in refusing to give effect to judgments of international human rights courts (IHRCs) with which they are in substantive disagreement, and the related argument that a 'democratic override' mechanism should be built into all strong international human rights law (SIHRL) frameworks to give adequate legal recognition to this 'right to disobey'. It examines the strength of the 'democratic constitutionalist' critique of IHRCs that underpins these arguments, and concludes that national parliaments will only be justified in refusing to give effect to judgments of IHRCs in exceptional circumstances. As a consequence, there exists no compelling reason to destabilise existing SILs to accommodate the rare instances where such national 'disobedience' will be justifiable. These arguments are developed with particular reference to the European Convention of Human Rights (ECHR), the best-developed SIHRL framework.
\end{abstract}

\section{Key Words}

Human rights, popular sovereignty, democratic override, constitutionalism, European Court of Human Rights.

\section{Introduction}

States which have agreed to be bound by 'strong' international human rights law (SIHRL) frameworks - such as the ECHR - are expected to respect and give effect to judgments of the supranational courts established to interpret and apply the provisions of the relevant human rights instruments. ${ }^{1}$ Thus Article 46 of the ECHR requires state parties to comply with judgments of the European Court of Human Rights (hereafter 'the Strasbourg Court'). Similarly, Article 68(1) of the American Convention on Human Rights imposes similar obligations in respect to judgments of the Inter-American Court of Human Rights. As the caselaw of these courts has developed, state parties to both these conventions have thus been obliged to adjust various elements of national law and policy to stay in conformity with their international law obligations. As a result, such SIHRL frameworks have come to play an important role in public governance: the freedom of action of national authorities, including national parliaments, is limited by the need to maintain conformity with their requirements.

This is particularly true of the ECHR. The case-law of the Strasbourg Court has come to exert wide-ranging influence over European legal systems. State parties to the Convention

\footnotetext{
${ }^{1}$ In contrast, 'weak' international human rights frameworks do not impose specific obligations upon state parties to give effect to decisions of the relevant adjudicative bodies. Examples would include the monitoring mechanisms established under the International Covenant on Civil and Political Rights and other UN human rights treaties.
} 
consistently defer to its decisions, ${ }^{2}$ while national authorities generally respect the legal norms laid down by the Court. As a result, the Court's jurisprudence exerts a considerable influence over the functioning of democratic governance across Europe. ${ }^{3}$

Indeed, the authority now exerted by the Strasbourg Court is sometimes cited as an example of how European states have abandoned rigid adherence to state-centred constitutionalism and embraced 'legal cosmopolitanism', understood to involve the subordination of national laws to transnational human rights norms and the elevation of the individual, as distinct from the nation or the state, as the main focus of legal concern. ${ }^{4}$ In general, SIHRL frameworks are often viewed as key vectors of legal cosmopolitanism - while the deference shown by national institutions to the judgments of IHRCs is regularly cited as evidence that states are no longer complete masters of their own domains.

However, for all this talk, SIHRL regimes still exist in a legal framework which is still predominantly shaped by what Kumm describes as the 'statist paradigm', i.e. the assumption that the state remains the locus of legitimate legal and political authority. ${ }^{5}$ The authority of IHRCS is based upon the consent of states to be bound by their judgments, which can - at least formally - be withdrawn by a state denouncing the relevant treaty instrument. Furthermore, as decisions of IHRCs do not have direct effect within national law (unlike for example, judgments of the Court of Justice of the EU), their authority is contingent upon the willingness of national authorities to give effect to their judgments: IHRCs cannot require national parliaments, executives or courts to defer to their determinations, as the prisoner voting saga discussed by Ed Bates in the preceding chapter has illustrated in the context of the UK and ECHR. Finally, IHRCs may as a matter of international law have the final say as to how the provisions of human rights treaties are to be interpreted and applied. However, their authority in this respect co-exists with the potentially competing authority claims of national constitutional actors, who as a matter of domestic law generally retain the final say when it comes to determining the content of national law.

Taken together, this means that IHRCS occupy an uncertain place in a legal order which remains structured around the principle of state sovereignty. Their functioning reflects a cosmopolitan understanding of the relationship between national law and supranational human rights standards, but this plays out against a background which remains dominated by the 'statist paradigm'. As a result, the relationship between SIHRL frameworks and domestic legal systems is inevitably pluralist, flexible and 'heterarchical' in nature, to use Krisch's terminology. ${ }^{6}$ National authorities must be persuaded to defer to judgments of IHRCs if their

\footnotetext{
${ }^{2}$ Certain countries have better compliance records than others: for a discussion of the attitude of the Russian Federation to the Court, see J. Lapitskaya, 'ECHR, Russia, and Chechyna: Two is not company and three is definitely a crowd', New York University Journal of International Law and Politics, 43 (2) (2010-11), 479-548.

${ }^{3}$ Various commentators have argued that the Strasbourg Court now functions in effect as a type of pan-European constitutional court, at least when it comes to legal issues that concern questions of fundamental rights: see e.g. S. Greer, The European Convention on Human Rights: Achievements, Problems and Prospects, (Cambridge: Cambridge University Press, 2006). However, this 'constitutional court' analogy is problematic in certain respects, and needs to be applied with care.

${ }^{4}$ See e.g. A. Stone Sweet, 'A Cosmopolitan Legal Order: Constitutional Pluralism and Rights Adjudication in Europe', Journal of Global Constitutionalism 1(1) (2012), 53-90.

${ }^{5}$ M. Kumm, 'The Cosmopolitan Turn in Constitutionalism: On the Relationship Between Constitutionalism in and Beyond the State', in J. L. Dunoff \& J. P. Trachtman (eds.) Ruling The World? Constitutionalism, International Law, and Global Governance (Cambridge: Cambridge University Press, 2009), p. 258 - 325, 315. ${ }^{6}$ N. Krisch, 'The Open Architecture of European Human Rights Law', Modern Law Review, 71(2) (2008), 183216.
} 
interpretation of human rights standards are to be respected and implemented - and this inevitably imposes certain de facto constraints upon IHRCs in developing their case-law. ${ }^{7}$ However, the ability of national authorities to reject judgments of IHRCs and thus to evade their treaty obligations is also subject to substantial legal and political limitations. ${ }^{8}$

The slippery and uncertain nature of this relationship inevitably ends up generating a degree of tension between IHRCs and national authorities. Such tensions can often be mediated through a process of inter-institutional dialogue. However, at times, they cannot be easily resolved, as again illustrated by the UK prisoner voting saga. When that happens, the uncertain nature of the relationship between SIHRL frameworks and national legal systems is exposed. Is it possible to reconcile the inherent cosmopolitanism of the former with the statist orientation of the latter? Are there circumstances in which national institutions can legitimately refuse to give effect to judgments of IHRCs? When might a state be justified in arguing that IHRCs have exceeded the permissible bounds of their authority, or even choose to repudiate its obligations under an instrument such as the ECHR?

No easy answers exist to any of these questions. Some commentators like to point to the binding nature of the legal obligations states assume when they ratify an instrument such as the ECHR, and suggest that this should end all debate in this context. But this is too simplistic. It ignores the manner in which issues of compliance with SIHRL norms are linked to wider issues relating to the legitimacy of supranational adjudication and its relationship to democratic governance at national level. It also glosses over the reality that the SIHRL mechanisms designed to secure state compliance with IHRC judgments afford national authorities a degree of wriggle room, which they can use to delay, minimise or even evade their obligation to abide by IHRC rulings while still formally adhering to the norms of the relevant treaty framework in question. ${ }^{9}$ Legal formalism does not provide clear answers to the question of how states should behave when called upon to give effect to IHRC judgments of which they disapprove.

Instead, what is required is greater normative clarity as to the norms that should guide state conduct in this regard. In particular, the question arises as to when it is legitimate for national authorities - and specifically national legislatures, as the primary law-making body within any given national constitutional framework - to refuse to give effect to a judgment of IHRCs? Such acts of 'civil disobedience' - viewed from the perspective of international law, if not from the perspective of domestic law - are rare, especially within the framework of the ECHR. States often seek to minimise or circumvent the impact of Strasbourg judgments on their domestic law, or drag their feet in giving effect to them: however, a refusal to give effect to a judgment is a 'nuclear option' which states have historically been slow to use. However, the possibility of its deployment can cast a perpetual shadow over the relationship between Strasbourg and national legislatures, as illustrated by the current debate in the UK on the status of the ECHR, as again described by Ed Bates in this book. As a result, it is necessary to discuss when national parliaments may legitimately ‘disobey' binding judgments of IHRCs - which in turn involves

\footnotetext{
${ }^{7}$ Cali has described this 'problematic' as constituting a permanent 'crisis of political legitimacy' for the Strasbourg Court. See B. Cali, 'The Limits of International Justice at the European Court of Human Rights: Between Legal Cosmopolitanism and "A Society of States"”, in M.-B. Dembour and T. Kelly (eds.), Paths to International Justice: Social and Legal Perspectives (Cambridge: Cambridge University Press, 2007), p. 111-133.

${ }^{8}$ Ibid.

${ }^{9}$ For example, the UK has dragged its feet in giving effect to the Hirst $v$ UK (No 2) (2005) 42 EHRR 41 judgment on prisoner voting for over ten years.
} 
some consideration of what constitutes the basis of the authority exercised by IHRCs, as well as its potential limits.

\section{Contesting the Authority of IHRCs: The 'Mandate Abuse' and 'Democratic Constitutionalist' Lines of Attack}

The authority of IHRCs is generally viewed as founded upon state consent. Once states ratify an international treaty, they are assumed to be bound by its provisions, including any requirement to comply with decisions of any adjudicative body established under that treaty. ${ }^{10}$ Thus, for example, the authority of the Strasbourg Court is founded upon the agreement of state parties to establish the Strasbourg Court and to abide by its judgments, as set out in Articles 32 to 51 of the ECHR. This voluntary commitment is generally understood both to confer legitimacy upon the Strasbourg Court and also to impose a binding normative obligation on state parties to respect its decisions, in line with the principle of pacta sund servanda. ${ }^{11}$

However, as Cali notes, this 'standard account' of why judgments of IHRCs should be viewed as binding upon state parties is vulnerable to a number of potential objections. In particular, it is open to the challenge that at best it establishes a pro tanto obligation to respect decisions of IHRCs, which can be outweighed by states invoking principled reasons for disregarding this obligation. ${ }^{12}$

In particular, two sets of principled reasons are periodically put forward by states as to why they would be justified in disregarding an IHRC judgment, namely that the IHRC in question has (i) exceeded the limits of its mandates (the 'mandate abuse' objection) and/or (ii) is exercising authority over national law to a degree which is incompatible with the democratic constitutionalist ideal that a state should ultimately be governed by institutions which are established by and accountable to a national demos (the 'democratic constitutionalist' objection). As discussed below, it is the 'democratic constitutionalist' objection that offers the most serious challenge to the authority of IHRCs - and is also the harder to rebut.

\subsection{The 'Mandate Abuse' Objection}

The first line of attack - the 'mandate abuse' claim - is invoked when national authorities object to judgments of an IHRC on the basis that the court in question has exceeded the scope of its mandate and thereby is no longer operating within the bounds of what Cali describes as the 'democratic endorsement international law receives at the time of its making'. ${ }^{13}$ In essence, this claim is structured around the assumption that the obligation of state parties to abide by judgments of an IHRC does not extend to judgments which unduly stretch the finite scope of the interpretative mandate originally conferred upon the IHRC in question. IHRCs are viewed as having been 'lent' their powers by state parties who use them as agents in advancing a

\footnotetext{
${ }^{10}$ Cali describes how the 'standard account' of the authority claims of international law is based in part upon a 'relaxed notion of [state] consent': see B. Cali, 'The Disciplinary Account of the Authority of International Law: Does It Stand Firm against Its External Critics?', European Society of International Law: Reflection, 5(5) 10 May 2016, available at http://www.esil-sedi.eu/node/1329 (last accessed 30 May 2016). See also in general B. Cali, Authority of International Law: Obedience, Respect and Rebuttal (Oxford: Oxford University Press, 2015). ${ }^{11}$ G. Letsas, 'The ECHR as Living Instrument: Its Meaning and Legitimacy', in G. Ulfstein, A. Føllesdal and B. Peters (eds.) Constituting Europe: The European Court of Human Rights in a National, European and Global Context (Cambridge: CUP, 2013), 106-141, p. 138-141.

${ }^{12}$ Cali, 'The Disciplinary Account'.

${ }^{13}$ Ibid.
} 
common purpose: however, if an IHRC oversteps the limits of its assigned authority, then the state is not bound by its decisions.

This is the type of argument made by British politicians when they assert that the judgments of the Strasbourg Court relating to prisoner voting rights represent an unjustified extension of its original, limited interpretative function - namely to interpret and apply the ECHR as establishing minimum guarantees against serious abuses of rights such as those committed by Fascist dictatorships during the 1930s and 1940s. As Bates notes in the previous chapter, this allegation that the Strasbourg Court has abused its mandate has been used to justify UK noncompliance with Hirst $v$ UK (No 2): in parliamentary debates, the Strasbourg Court has been accused of over-reaching itself and acting beyond the scope of the legitimate authority, thus entitling the UK Parliament to disregard its obligation under Article 46 of the ECHR to abide by this judgment of the Strasbourg Court.

However, claims of mandate abuse are relatively common - and often fail to establish a convincing case as to why national authorities are entitled to disregard an IHRC judgment. As Cali notes, IHRCs have been given the power to lay down binding decisions as to the scope and content of human rights norms precisely because no consensus exists among state parties as to how exactly these norms should be interpreted and applied. ${ }^{14}$ Furthermore, state parties have agreed to treat IHRC judgments as being legally binding, even if they disagree with their content: as Letsas puts it with reference to the Strasbourg Court, 'the ECHR contracting states wanted to create not only legally binding obligations but also legally binding determinations of when these obligations have been breached... ${ }^{15}$ By signing up to the jurisdiction of IHRCs, states have therefore committed themselves to accepting their judgments - which by extension entails accepting IHRC determinations as to the scope and content of the rights set out in the relevant treaty.

National authorities will thus only have substantial grounds for disregarding IHRC judgments if they can show that an IHRC clearly abused its interpretative mandate, by perhaps acting in bad faith or failing to reason in a principled manner: absent such special circumstances, mere disagreement with a decision is not a convincing basis for repudiating the voluntarily-assumed obligation of states to abide by IHRC judgments. ${ }^{16}$ Furthermore, given that IHRCs usually take considerable care to produce reasoned justifications for their decisions, states will generally struggle to show the existence of bad faith or blatantly flawed reasoning. As a consequence, national parliaments may often criticise an IHRC judgment and make allegations of mandate abuse - but they will only begin to establish a strong normative case for disregarding their selfimposed commitment to abide by that judgment if they can make a convincing case that the IHRC acted in bad faith or on the basis of wholly inadequate reasoning. ${ }^{17}$

\footnotetext{
${ }^{14}$ Ibid.

${ }^{15}$ Letsas, 'The ECHR as Living Instrument', p. 139.

${ }^{16}$ An analogy may be drawn here to the manner in which, in the private law of both common and civil law systems, principals will be deemed liable for the acts of their agents, irrespective of whether they endorsed or approved of these acts, as long as the act in question is the type of act the agent was authorised to do. See e.g. the English common law position as set out by Lord Nicholls in Dubai Aluminium Co Limited v Salaam \& Ors [2003] 2 AC 366, para. 122 .

${ }^{17}$ Letsas, 'The ECHR as Living Instrument', p. 139-141. For example, the judgment in Hirst v UK (No 2) (2006) 42 EHRR 41 would appear neither to involve 'bad faith or 'wholly inadequate reasoning': see in general C. Murray, 'We Need to Talk: "Democratic dialogue" and the ongoing saga of prisoner disenfranchisement' (2011) 62(1) Northern Ireland Legal Quarterly, 57-74.
} 


\subsection{The 'Democratic Constitutionalist' Objection}

The second line of attack - the 'democratic constitutionalist' claim - goes deeper than allegations of mandate abuse. Claims that IHRCs have exceeded their mandate implicitly assume that such courts will be acting legitimately if they respect the confines of that mandate, however defined; and, as discussed above, such claims are inherently difficult to establish. However, the democratic constitutionalist critique strikes at the heart of the legitimacy claims of SIHRL. It calls into question whether it is compatible with democratic first principles for IHRCs to play a significant role in shaping national law, and by extension whether national parliaments and other domestic authorities should consider themselves bound to give effect to IHRC judgments which they view as involving a substantial transgression upon popular sovereignty. ${ }^{18}$ It is also more difficult to rebut than allegations of mandate abuse, not least because it touches upon a fundamental point of uncertainty in the relationship between SIHRL and national legal systems.

This critique is built around the assumption that national authorities who are democratically accountable to a particular demos, or whose powers are derived from the exercise of the constituent power of that demos, should have primary responsibility for shaping the law of the land and determining the scope and content of fundamental rights - and that any substantive delegation of that law-shaping power to supranational institutions such as IHRCs, which lack a firm democratic constitutionalist foundation, is inherently problematic. ${ }^{19}$ According to this critique, the greater the extent to which the case-law of IHRCs restricts the freedom of action of national parliaments and other domestic law-making bodies, the greater the extent to which the principle of national self-determination is undermined. By logical extension, this suggests that national authorities are entitled to resist any such excessive transfer of authority, by refusing to abide by IHRC judgments which are deemed to constitute a substantial interference with the exercise of collective self-governance at the national level. ${ }^{20}$

In other words, this critique suggests that the authority of IHRCs is subject to certain limits derived from democratic first principles - and that national parliaments and other bodies will be entitled to 'disobey' IHRC judgments which they deem to be insufficiently respectful of the right of a sovereign people to govern themselves through the constituted form of the nation state. It also suggests that it is constitutionally unsound in general for IHRCs to play too influential a role in shaping national law, as this involves a transfer of power away from the

\footnotetext{
18 Buchanan and Powell describe these arguments as 'incompatibilist concerns', as they suggest that state deference to international law standards can be in incompatible with constitutional democracy: see A. Buchanan and R. Powell, 'Constitutional Democracy and the Rule of International Law: Are They Compatible?', Journal of Political Philosophy, 16(3) (2008), 326-349.

${ }^{19}$ N. Krisch, 'The Open Architecture of European Human Rights Law', Modern Law Review, 71(2) (2008), 183216; see also the discussion in A Kalyvas, 'Popular Sovereignty, Democracy and the Constituent Power', Constellations, 12 (2005), 223.

${ }^{20}$ This critique has particular resonance for states such as the UK, whose constitutional systems give their national legislatures (and not national courts) the final say over the scope and content of fundamental rights. However, any national institution charged by the demos with performing a decision-making role in this regard might potentially be able to invoke the democratic constitutionalist objection as a justification for refusing to give effect to an IHRC judgment: see for example the recent judgment of the 19 April 2016 issued by the Russian Constitutional Court relating to the ECHR case of Anchugov and Gladkov v Russia, Applications nos. 11157/04 and 15162/05, Judgment of 4 July 2013, discussed by K. Dzehtsiarou et al, 'Imaginary Dialogue and Fictitious Collaboration: Russian Response to the Prisoner Voting', ECHR Blog, 29 April 2016, available at http://echrblog.blogspot.co.uk/2016/04/the-russian-response-to-prisoner-voting.html (last accessed 29 May 2016).
} 
democratically unaccountable organs of the state to an unaccountable and inherently undemocratic supranational system of governance. ${ }^{21}$

In Europe, it used to be rare for the Strasbourg Court to attract criticism from this democratic constitutionalist perspective. However, things have changed - especially in the UK. In 2009, a leading British judge, Lord Hoffmann, took the opportunity of giving a lecture to the Judicial Studies Board on the verge of his retirement as a Law Lord to launch a full-on assault on the Strasbourg Court: he described the establishment of the Strasbourg Court as an 'error', and questioned why a supranational court which lacked a clear democratic constitutionalist mandate should exercise so much influence on the development of English law. ${ }^{22}$ Similar arguments have subsequently been made by other UK politicians and judges, ${ }^{23}$ and have influenced the decision of the Conservative Party in its 2015 election manifesto to commit itself to making 'our own Supreme Court the ultimate arbiter of human rights matters in the UK' ${ }^{24}$

In general, as discussed by Bates in the preceding chapter, the democratic constitutionalist critique has come to loom large in the UK debate about the status and legitimacy of the Strasbourg Court. Claims of mandate abuse in respect to the Hirst judgment still persist, but Strasbourg sceptics have widened their point of attack to include the entirety of the existing relationship between the ECHR and UK law. Some commentators have argued that a 'democratic override' should be built into the Strasbourg system of rights protection, allowing national parliaments to overturn decisions of the Court. ${ }^{25}$ Others have called for the UK to withdraw from the ECHR, on the basis that the binding obligation to abide by judgments of the Strasbourg Court is incompatible with the principle of democratic self-government and the established sovereign authority of the Westminster Parliament.

Similar concerns have been articulated in other European states, in particular Russia. ${ }^{26}$ In Latin America, democratic constitutionalist concerns are also increasingly being invoked to call the authority of the Inter-American Court of Human Rights into question. ${ }^{27}$ These same concerns

\footnotetext{
${ }^{21}$ Note that this democratic constitutionalist critique, which objects to international courts instead of national authorities having the 'final say' over important issues related to the enjoyment of fundamental rights, should be distinguished from critiques of judicial power that are based on political constitutionalist principles, which object to unelected judges having the final say over matters that should be determined by elected politicians. The two critiques will often overlap, especially in the situation of the UK where the elected legislature enjoys sovereign law-making powers. However, their points of emphasis can differ in significant ways: for example, the democratic constitutionalist concerns about national courts deferring to IHRC judgments is less likely to trouble political constitutionalists, who may in contrast prefer indirect judicial supervision by IHRCs to the more direct forms of supervision usually exerted by national apex courts: see R Bellamy, 'The Democratic Legitimacy of International Human Rights Conventions: Political Constitutionalism and the European Convention of Human Rights', European Journal of International Law, 25(4) (2015), 1019.

${ }^{22}$ Lord Hoffmann, 'The Universality of Human Rights', Law Quarterly Review, 125 (2009), 416.

${ }^{23}$ See e.g. the comments of Jack Straw MP, House of Commons Debate, 10 Feb 2011, cols. 502-504.

${ }^{24}$ UK Conservative Party, Manifesto 2015, p. 60.

${ }^{25}$ See e.g. M. Pinto-Duschinsky, Bring Rights Back Home: Making human rights compatible with parliamentary democracy in the UK (London: Policy Exchange, 2011), p. XX.

${ }^{26}$ See P. Leach and A. Donald, 'Russia Defies Strasbourg: Is Contagion Spreading?', EJIL Talk, 19 December 2015, available at http://www.ejiltalk.org/russia-defies-strasbourg-is-contagion-spreading/ (last accessed 27 May 2016). For a flavour of the criticism that the Strasbourg Court can occasionally attract in the Netherlands, see T. Baudet, 'The Anti-democratic Impulses of the ECHR: The European Court of Human Rights has become a ravening monster overriding the rights of individual states', Spiked Online, $19^{\text {th }}$ January 2011, available at http://www.spiked-online.com/index.php/site/printable/10087/ (last accessed 23th May 2016).

27 See e.g. Venezuela's denunciation of the jurisdiction of the Inter-American Court of Human Rights, analysed by J. Harrington, 'Venezuela Denounces American Convention on Human Rights', EJIL Talk, 12 September
} 
have also begun to feature more prominently in academic writing on the topic of SIHRL and the legitimacy of 'strong' international law norms more generally. For example, Jed Rubenfeld has questioned the democratic legitimacy of forms of international law which impose substantial constraints on state sovereignty, highlighting their lack of a firm grounding in an exercise of the popular will. ${ }^{28}$ In the European context, Andreas von Staden has highlighted the need for IHRCs to be guided by a strong attachment to the principle of 'normative subsidiarity' if they are to compensate for their limited democratic legitimacy and the manner in which their authority sits uncomfortably with the 'ideal of self-government' that he sees as forming the core of democracy. ${ }^{29}$

The increased salience of the democratic constitutionalist critique in contemporary debates about SIHLR is striking. It arguably reflects wider concerns about international law becoming a tool of 'domination', as Cali puts it - i.e. a mode of governance that limits the exercise of democratic choice at national level. ${ }^{30}$ The case-law of IHRCS, as seen in the Strasbourg Court, now imposes a relatively substantial degree of restraint upon the freedom of action of national authorities, at a time when human rights values are under political attack: it is thus not surprising that challenges to the authority of IHRCs are increasingly framed in the language of democratic constitutionalism.

The democratic constitutionalist objection thus has potency. It enables national parliaments and other state parties to make a democratic case as to why they are entitled to 'disobey' their obligation to give effect to IHRC judgments in order to vindicate the principle of popular sovereignty. As such, this objection has a deeper normative grounding than allegations of mandate abuse, and is easier to justify: it invokes democratic first principles to call into question the inherent legitimacy of IHRCs, irrespective of the virtues or vices of their caselaw. It is also a form of attack that national parliaments are particularly well-positioned to deploy, given their claim to be the directly elected representatives of the people at large - as demonstrated by the rhetoric used by parliamentarians in the prisoner voting controversy in the UK.

The democratic constitutionalist objection is therefore likely to loom large in future interactions between national parliaments and IHRCs, and is much less easy to dismiss than claims of mandate abuse. Therefore, the rest of this paper will focus on this critique of the authority of IHRCs and the influence they exert over national law, and the arguments that can be made in response.

\section{Trying (and Failing?) to Justify the Authority of IHRCs - Amelioration, Consent and Democratic Constraint}

2012, available at http://www.ejiltalk.org/venezuela-denounces-american-convention-on-human-rights/ (last accessed 28 May 2016).

${ }^{28}$ J. Rubenfeld, 'Unilateralism and Constitutionalism', New York University Law Review, 79 (2004), 1971.

${ }^{29}$ A. von Staden, 'The Democratic Legitimacy of Judicial Review Beyond the State: Normative subsidiarity and judicial standards of review', I-CON, 10(4) (2012), 1023. See also S. Wheatley, 'On the Legitimate Authority of international Human Rights Bodies', in A. Føllesdal, J.K. Schaffer and G. Ulfstein (eds) The Legitimacy of International Human Rights Regimes (Cambridge: CUP, 2013), 103; and note von Bogdandy and Venzke's nuanced analysis in A. von Bogdandy and I. Venzke, 'In Whose Name? An Investigation of International Courts' Public Authority and Its Democratic Justification', European Journal of International Law, 23(1) (2012), 7-41.

${ }^{30}$ Cali, 'The Disciplinary Account'. 
Various commentators have attempted to downplay the force of the democratic constitutionalist critique, or to explain it away. However, many of these responses have struggled to provide a convincing rebuttal to this critique - or, to be more precise, have failed to deliver a knock-out blow.

\subsection{The First Response - Amelioration}

Enthusiasts for SIHRL have in general been slow to engage with the democratic constitutionalist critique. Instead, they often prefer to emphasise the prudential arguments as to why states should adhere to their international treaty commitments, defend the integrity of the interpretative practices and legal reasoning deployed by IHRCs, point to the manner in which state parties get a say in electing judges to these courts and/or draw attention to the considerable room for manoeuvre that states enjoy when it comes to giving effect to IHRC judgments. ${ }^{31}$ Much of the recent literature has also extolled the virtues of 'dialogue' between IHRCs and national authorities, ${ }^{32}$ or has otherwise analysed how to improve the quality and consistency of the jurisprudence of IHRCs with a view to enhancing their social and normative legitimacy. ${ }^{33}$

In other words, commentators who are favourably inclined towards IHRCs have tended to respond to the democratic constitutionalist critique by highlighting ways in which the tensions that exist between SIHRL and the principle of popular sovereignty can be 'managed' or 'ameliorated', i.e. addressed through prudential responses by relevant institutional actors and/or developments in legal reasoning that could help to reinforce the legitimacy of the status quo. These lines of argument are perfectly sound, within their own terms. They provide useful insights as to how democratic constitutionalist concerns about the authority of IHRCs can be assuaged, or at least smoothed over to some degree.

However, these arguments do not really engage with the more fundamental issues at stake. As Kyritsis neatly puts it in his chapter in this book, deference by national authorities to IHRC judgments can be viewed as breaking 'the line of authorization that must presumably connect every political decision with the will of a self-governing people': arguments to the effect that the impact of this 'break' can be contained, managed or ameliorated thus do not by themselves engage directly with the force of this democratic constitutionalist critique. Even if effective steps are taken to ameliorate the tensions that arise in this context, the underlying issues remain in play - and any relief is likely to be temporary.

\subsection{The Second Response - Relying upon Consent}

Other commentators have responded to the democratic constitutionalist critique by arguing that the agreement of democratically accountable national authorities to be bound by judgments of IHRCs provides a sufficient democratic constitutionalist basis for their authority: the representatives of the demos have agreed to abide by IHRC judgments, and are consequently obliged to show fidelity to the terms of their agreement even if they disagree with specific case

\footnotetext{
${ }^{31}$ As a regular participant in public debates about the ECHR in the UK, the author has noted the frequency with which defenders of the Strasbourg Court make these specific arguments in the context of the ongoing Hirst controversy.

${ }^{32}$ See e.g. L. Glas, The Theory, Potential and Practice of Procedural Dialogue in the European Convention on Human Rights System (London: Intersentia, 2016).

${ }^{33}$ See e.g. K. Dzehtsiarou, European Consensus and the Legitimacy of the Strasbourg Court (Cambridge: Cambridge University Press, 2015).
} 
outcomes. ${ }^{34}$ James Nickel has even argued that 'tacit consent' on the part of national authorities to the evolving interpretative practices of IHRCs can provide a sufficient normative basis for the obligation to abide by their judgments. ${ }^{35}$

But these consent-based arguments constitute a relatively tenuous response to the democratic constitutionalist objection. ${ }^{36}$ Does consent, whether explicit or tacit in nature, really provide enough of a normative basis on which to ground the wide-ranging authority exercised by a body such as the Strasbourg Court - especially given that national parliaments often only play an indirect role in approving state ratification of international treaties? Can fidelity to the pacta sund servanda principle really outweigh democratic constitutionalist concerns? At what point can any such consent be qualified and/or subject to new conditions? Are there circumstances in which the constraints imposed by IHRC judgments on the functioning of democratic governance at national level may be so great as to justify a refusal by a national parliament to adhere to its existing commitments under SIHRL?

Furthermore, consent-based arguments do not provide any substantial reasons as to why a state party should be reluctant to withdraw its consent to be bound by the judgments of an IHRC, by exercising its right under the relevant international treaty to denounce the jurisdiction of the relevant court. At best, consent-based justifications provide an argument as to why a state that has ratified an international human rights treaty should continue to respect its provisions as long as it remains a party to the relevant treaty instrument. However, they provide no real justification as to why a state should not denounce that instrument, if it decides that it no longer wishes to be bound by its provisions: the state in question would not be breaching any treaty commitments in so doing, and therefore could not be accused of breaching the pacta sund servanda principle.

This weakness in content-based justifications for the authority of IHRCs is often overlooked. In debates about the authority of IHRCs, it is often assumed that state denunciation of their governing treaty instrument is not a viable option for political reasons - and that only outlier states such as Venezuela will ever avail of this option. But the current UK Home Secretary, Theresa May MP, has supported it as a solution to the democratic constitutionalist concerns generated by the authority of the Strasbourg Court - while the UK government has refused to rule it out as a possible long-term policy option. ${ }^{37}$ Consent-based justifications for the authority exercised by IHRCs cannot provide any real rationale as to why such a step would be normatively problematic - thereby illustrating the shallow nature of the principled foundations it purports to provide for SIHRL in general, and the response it is supposed to offer against democratic constitutionalist concerns in particular.

\subsection{The Third Response - The Argument from Democratic Constraint}

A third group of commentators have suggested that the democratic constitutionalist critique lacks force precisely because IHRCs play an important role in checking abuses of democratically-derived authority at national level. They argue that the standard justifications

\footnotetext{
${ }^{34}$ See e.g. Letsas, 'The ECHR as a Living Instrument', p. 139-141.

35 J. Nickel, On Making Sense of Human Rights (Malden: Blackwell, 2007), p. 47.

${ }^{36}$ The situation is different in respect of mandate abuse claims, as discussed above: in that context, consent plays an important role in defining the scope of an IHRC's mandate.

${ }^{37}$ See T. May, 'Speech on Brexit', 25 April 2016, available at

http://www.conservativehome.com/parliament/2016/04/theresa-mays-speech-on-brexit-full-text.html (last accessed 29 May 2016).
} 
put forward to justify judicial rights review at domestic level - such as the need to protect minorities, or to subject the exercise of state power to checks and balances - also serve to legitimate the authority exercised by the Strasbourg Court and other IHRCs. ${ }^{38}$ In other words, this line of argument maintains that the democratic constitutionalist critique lacks bite because the role of SIHRL in general, and of IHRCs in particular, is to protect individual rights against majoritarian pressures at the domestic level.

By themselves, these arguments struggle to explain why IHRCs play a distinct and necessary role in discharging these rights-protective functions, as distinct from (for example) the national courts which perform a similar role. However, an accompanying claim is often made to the effect that IHRCs add a valuable additional dimension to domestic forms of legal rights protection: they provide an external point of scrutiny, and ensure that states may be called upon to justify infringements of fundamental rights in an international forum which is insulated to a degree from the political pressures and prevailing ideological prejudices that may apply at national level. ${ }^{39}$ Dworkin has also made the additional argument that international human rights frameworks play an important role in helping to redress the vulnerability of individuals to the coercive power of the state in which they reside: fidelity to SIHRL regimes such as the ECHR thus enhances state legitimacy vis-à-vis their citizens, by providing external constraints on the exercise of state power. ${ }^{40}$ Føllesdal and Cali have similarly argued that the rights review role of IHRCs establishes an intrinsically valuable three-way accountability relationship between bodies such as the Strasbourg Court, states and the individuals subject to their jurisdiction. ${ }^{41}$ Buchanan suggests that the requirements of SIHRL, including the obligation to abide by IHRC judgments, can be partially justified by the manner to which it helps to protect individuals against the risks inherent in an international legal order which confers 'eminently abusable powers and privileges' on states. ${ }^{42}$

All these arguments have considerable force. However, in and of themselves, they cannot trump the democratic constitutionalist objection. In democracies founded upon the principle of popular sovereignty, even institutions exercising majoritarian-checking powers are expected to be established on the basis of an exercise of constituent power by a national demos. As Samantha Besson has argued, human rights protection 'ought to be the outcome of a legalisation process in which human rights-holders can also be the authors of their own rights' ${ }^{43}$ In other words, even counter-majoritarian rights protective institutions are (perhaps paradoxically) assumed to derive their legitimacy at least in part from the principle of popular

\footnotetext{
${ }^{38}$ See e.g. A. Føllesdal, 'The Legitimacy of International Human Rights Review: The case of the European Court of Human Rights', Journal of Social Philosophy, 40 (2009), 595-607; J. Mayerfeld, 'The Democratic Legitimacy of International Human Rights Law', Indiana International and Comparative Law Review, 19(1) (2009), 49-88.

${ }^{39}$ Mayerfeld, 'The Democratic Legitimacy', 79-86.

${ }^{40}$ R. Dworkin, 'A New Philosophy of International Law', Philosophy and Public Affairs, 41 (2013), 2.

${ }^{41}$ Føllesdal, 'The Legitimacy of International Human Rights Review', 595-607.; B. Cali, 'The Legitimacy of International Interpretive Authorities for Human Rights Treaties: An indirect-instrumentalist defence', in A. Føllesdal, J.K. Schaffer and G. Ulfstein (eds) The Legitimacy of International Human Rights Regimes (Cambridge: CUP, 2013), p. 141-164.

42 A. Buchanan, The Heart of Human Rights (Oxford: Oxford University Press, 2013), ch. 4.

${ }^{43}$ S. Besson, 'Human Rights and Democracy in a Global Context: Decoupling and recoupling', Ethics \& Global Politics, 4(1) (2011), 19-50, 30. Mayerfeld contests this, arguing that '[i]t is a mistake...to suppose that human rights themselves require our consent': Mayerfeld, 'The Democratic Legitimacy', 78. But, irrespective of the philosophical merits of this position in the abstract, it is difficult to see why a specific institutional system of rights protection such as SIHRL should be exempt from the expectation that it should be compatible with the principle of popular sovereignty, especially given that such a system co-exists with other more or less effective mechanisms for protecting rights at the national and international level.
} 
sovereignty - reflecting how rights and democracy are, in Besson's expression, 'coupled' together. ${ }^{44}$ However, the democratic basis of the authority exercised by IHRCs is generally quite tenuous, and often lacks any firm basis in an exercise of the popular will. ${ }^{45}$

As a consequence, the argument that the authority of IHRCs can be justified on the basis of the extra international dimension it adds to domestic forms of rights protection is vulnerable to the charge that this extra dimension lacks much in the way of a tangible democratic basis. SIHLR may thus add a layer of useful additional rights protection to what is on offer at the national level, but this by itself does not constitute a sufficient response to the democratic constitutionalist objection.

This vulnerability is illustrated by the current UK debate, where politicians and judges who are critical of the Strasbourg Court repeatedly query the need for an additional European layer of legal rights protection which only supplements what is already on offer from Parliament and the British courts. ${ }^{46}$ In their view, any added value that the Strasbourg Court contributes to better rights protection is outweighed by its lack of substantive democratic foundations. ${ }^{47}$

\section{Taking Democratic Constitutionalism Seriously - Can States Legitimately 'Disobey' IHRC Judgments?}

At best, these standard responses to the democratic constitutionalist critique provide valid reasons as to why national authorities should continue to abide by the judgments of IHRCs, absent some particular reason to reject them on the basis of democratic insufficiency. In other words, they provide adequate justification as to why judgments of IHRCs should in general be treated as content-independent, authoritative and binding on national authorities (to use the language of Raz's 'normal justification' thesis). ${ }^{48}$ However, national authorities must also maintain fidelity to the principle of popular sovereignty and to adhere to their own

\footnotetext{
44 Ibid.

${ }^{45}$ Stone Sweet has argued that the ECHR has been incorporated into European legal systems via an 'inherently constitutional process': see A. Stone Sweet, 'The European Convention on Human Rights and National Constitutional Ordering', Cardozo Law Review, (2012) 33(5), 1859-1868. However, it is rare for state ratification of the ECHR and acceptance of the binding authority of the Strasbourg Court to be underpinned by a constitutional provision or some other formal expression of the popular will. (This stands in interesting contrast to the situation with EU law and the authority of the Court of Justice of the EU, which is generally underpinned by national constitutional provisions which have often been approved via a referendum procedure or some other direct expression of the popular will.) What Stone-Sweet describes as the 'national constitutional reordering' generated by the influence now exerted by the Strasbourg Court over European legal systems has in general been brought about by national executives, legislatives and judiciaries choosing to defer to Strasbourg case-law, rather than being the product of democratic authorisation from the people at large.

${ }^{46}$ See in general Hoffmann, 'The Universality of Human Rights'.

${ }^{47}$ See e.g. the analysis set out in Pinto-Duschinsky, Bring Rights Back Home.

${ }^{48}$ Raz's normal justification thesis, which forms an important element of his general 'service conception' of authority, states that the normal way to establish that an institution is justified in exercising authority involves demonstrating that the putative subjects of its authority are 'better to comply with reasons which apply to them' by treating the institution's directives as content-independent, authoritative and binding reasons for action that if they adopted some other guide, or tried to follow reasons that apply to them directly: see J. Raz, The Morality of Freedom, (Oxford: Oxford University Press, 1985), p. 53-69; J. Raz, 'The Problem of Authority: Revisiting the Service Conception', Minnesota Law Review, (2006) 90, 1014. For a useful discussion of the applicability of Raz's thesis in the context of international law, see the chapters by A. Buchanan, 'Human Rights and the Legitimacy of the International Order,' and J. Tasioulas, 'The Legitimacy of International Law', in S. Besson and J. Tasioulas, The Philosophy of International Law (Oxford: Oxford University Press, 2010), p. 79-96 and p. 97 116 respectively.
} 
constitutionally-mandated system of law-making. ${ }^{49}$ As such, there may be circumstances in which the reasons that national authorities have to abide by judgments of IHRCs are outweighed by more demanding considerations, namely the need to respect the core democratic constitutionalist framework of the state in question.

National parliaments and other state organs may thus be entitled to 'disobey' a judgment of an IHRC, or even to repudiate an entire SIHRL regime, if such an act of disobedience can legitimately be shown to be necessary to vindicate popular sovereignty. The legal obligation to abide by IHRC judgments as set out in treaty provisions like Article 46 of the ECHR is therefore best viewed in normative terms as a presumptive or 'rebuttable' duty, to use Cali's phraseology: it may be legitimately disregarded when states 'are able to show that an equally important other duty is preventing them from performing it', such as the duty to maintain fidelity with constitutional democratic principles. ${ }^{50}$ The democratic constitutionalist objection thus has both normative and political bite: it provides a platform on which national authorities - and in particular national parliaments - can build an arguable case as to why it is legitimate for them to disobey IHRC judgments.

However, in acknowledging that democratic constitutionalist concerns may justify state disobedience of IHRC judgments, it is important to recognise that this does not entitle national parliaments and other state organs to play this trump card every time they object to a court decision that goes against them. As Cali notes, a legal duty such as the obligation to abide by IHRC judgments will only be 'rebuttable' if a state can demonstrate that it would be otherwise impossible for it to give effect to another equally important duty - any other approach would end up nullifying the assumed intention of state parties to establish a binding set of treaty norms. ${ }^{51}$

In other words, democratic constitutionalist concerns can only be invoked to justify noncompliance with IHRC rulings in exceptional circumstances, when the principle of popular sovereignty is at clear risk of being undermined. Furthermore, as discussed below, similar reasoning may apply to limit the circumstances in which a state might justifiably chose to denounce its treaty obligations to respect IHRC judgments.

\section{Crossing the Threshold - When May States Legitimately Disobey an IHRC Judgment?}

State 'disobedience' to an IHRC judgment will therefore only be normatively justified in situations where the obligation to give effect to such judgments risks undermining popular sovereignty. But any controversial IHRC decisions will almost inevitably generate claims that this threshold has been crossed. So the question becomes in which circumstances will a state be justified in claiming that its obligation to abide by an IHRC judgment is incompatible with the first principles of democratic constitutionalism - or, to put it another way, when exactly will national parliamentarians be justified in crying wolf?

This is a complex issue. Different views will inevitably exist as to when a specific IHRC judgment might cross the line, or when the influence of an IHRC - in general - over the shaping of national law has become so great as to justify 'civil disobedience' on the part of a state.

\footnotetext{
${ }^{49}$ See in general Buchanan and Powell, 'Constitutional Democracy and the Rule of International Law'.

${ }^{50}$ Cali, 'The Disciplinary Account'.

${ }^{51}$ Ibid.
} 
Trying to fix a hard and fast test in this regard is likely to be an exercise in futility, not least because the relevant 'red lines' may vary from state to state. ${ }^{52}$ However, certain relevant factors can be identified, which may help to clarify when national parliaments and other state organs will be acting legitimately in refusing to give effect to a judgment of an IHRC, or indeed electing to denounce their treaty obligations to respect such judgments in their entirety.

First of all, states with an attenuated or purely nominal national democratic system, or whose legal system provides little if any effective protection for fundamental rights, will invariably struggle to justify disobeying an IHRC judgment. Asserting a right to disobey an IHRC decision on the basis that it is incompatible with a state's commitment to the principles of democratic constitutionalism requires that a state takes these principles seriously in the first place. ${ }^{53}$ The argument could also be made that unstable democracies, or societies emerging from conflict, should be exceptionally slow to disobey IHRC judgments, given that their domestic democratic constitutionalist frameworks will be inherently fragile.

Secondly, as Buchanan and Powell have argued, the fact that international law obligations may limit the freedom of action of state organs does not by itself mean that the principle of popular sovereignty has been undermined. ${ }^{54}$ National authorities - including national parliaments - are subject to multiple constraints on their ability to make free use of their powers. In particular, transnational regulation invariably imposes certain limitations on their freedom of manoeuvre. But, as Buchanan and Powell note, democratic polities often have good reasons to accept these external constraints. ${ }^{55}$ They may be necessary to enable states to co-ordinate their behaviour in the interest of achieving common goals - such as securing greater respect for human rights on a cross-border basis. ${ }^{56}$ Furthermore, it is common for such agreements to contain clauses requiring state parties to defer to decisions of adjudicative bodies: SIHRL does not differ in this respect from other areas of international law. Accepting such constraints on the sovereign power of the state is part and parcel of modern governance.

As such, Buchanan and Powell are correct when they argue that deference to rigorous international law' standards such as the EHRC will only become incompatible with democratic constitutionalist principles when a particular tipping-point is reached, namely when the 'diminution of self-determination in a constitutional democracy become so great as to be incompatible with it warranting the title of a democracy, a territory whose inhabitants are in some meaningful sense self-governing'. ${ }^{57}$ An obligation to abide by an IHRC judgment which offends public opinion, or restricts the freedom of action of a national parliament, will not necessarily meet this threshold: national authorities will need to point to a more fundamental concern - which cuts to the core of what it means to be a self-governing state founded on the

\footnotetext{
${ }^{52}$ Buchanan and Powell have suggested that a possible 'red line' in this regard would be if compliance with strong international law standards begins to cause substantial alterations to 'existing constitutional structures': see Buchanan and Powell, 'Constitutional Democracy and the Rule of International Law', 345-347. However, this test may be too circular and question-begging to be of much use: the question of whether deference to IHRCs is incompatible with the rules of the existing constitutional system is exactly the point at issue in this regard.

${ }^{53}$ The reader is invited to decide for herself which member states of the Council of Europe or Organisation of American States might struggle to meet this qualifying condition.

${ }^{54}$ Buchanan and Powell, 'Constitutional Democracy and the Rule of International Law', 326.

55 Ibid.

${ }^{56}$ Buchanan, The Heart of Human Rights, ch. 4.

${ }^{57}$ Buchanan and Powell, 'Constitutional Democracy and the Rule of International Law', 344.
} 
basis of popular sovereignty - is required before states will be able to credibly invoke their 'right to disobey'.

Thirdly, to add another element into the mix, it is also important to bear in mind that the influence exerted by IHRCs over the shaping of national law need not be inherently counterdemocratic. Instead, it can be argued that it often serves to deepen respect for democratic constitutionalist principles both within and outside a state, rather than undermining them. As a consequence, it will often be too simplistic to frame conflict between IHRCs and national authorities as a straightforward matter of supranational regulation eroding popular sovereignty - which in turn inevitably complicates the task of defining the circumstances when a state will be justified in disobeying an IHRC judgment, or denouncing its treaty obligations to respect such judgments in their entirety.

In this regard, it can be argued that IHRCs make a distinct and unique contribution to reinforcing democratic constitutionalism within states subject to their jurisdiction. Democratic constitutionalism derives its claim to normative legitimacy from how it unifies respect for democratic will-formation while maintaining a commitment to respect the principle of equal liberty of all its citizens by adhering to the rule of law, respecting rights and so on. As Habermas argues, this 'internal relation' between the exercise of democratic will and the commitment to reason develops as a 'self-correcting learning process' through which lessons are learnt on an incremental basis as to how both principles can be better blended together. ${ }^{58}$ IHRCs can make a distinct contribution to this 'learning process'. Their judgments can help to pinpoint where tensions may exist between state law generated by the process of democratic will-formation and the normative logic of human rights, by bringing a detached external perspective to bear on issues in respect of which national law may have developed a blind spot. ${ }^{59}$ Kjaer thus argues that 'nation-state law...in essence remains oriented toward the upholding of already established normative expectations', but 'transnational law' such as the ECHR, functions as a 'learning process', helping national law adopt and adjust to the existence of other normative expectations that lie outside its traditional purview. ${ }^{60}$ Bellamy and Buchanan have made similar arguments. $^{61}$

In addition, IHRCs play some part in addressing a latent tension that lies at the heart of democratic constitutionalism, namely how it is predicated upon the assumption that all persons should enjoy 'equal liberty' but then confines participation rights to citizens. Benhabib

\footnotetext{
58 J. Habermas, Constitutional Democracy: A Paradoxical Union of Contradictory Principles?, Political Theory 29 (2001), 766, 766-769.

${ }^{59}$ Indeed, many IHRC decisions have come over time to be acknowledged as significant turning-points in the evolution of national constitutional systems: they are absorbed into the 'story' of the unfolding rational development of domestic law. For example, this is the case with the development of key areas of UK law relating to the protection of civil liberties and fundamental rights: see in general C. O'Cinneide, 'Human Rights and the UK Constitution', in J. Jowell, D. Oliver and C. O'Cinneide (eds.), The Changing Constitution $8^{\text {th }}$ ed (Oxford: Oxford University Press, 2015), p. 67-103.

60 P. Kjaer, 'The Metamorphosis Of The Functional Synthesis: A Continental European Perspective On Governance, Law, and the Political In The Transnational Space', Wisconsin Law Review, (2010), 489-533, 489. See also G. de Búrca and O. Gerstenberg, 'The Denationalisation of Constitutional Law', Harvard Journal of International Law, 47(1) (2006), 243-262, 257-8.

61 R. Bellamy, 'The Democratic Legitimacy of International Human Rights Conventions: Political Constitutionalism and the European Convention of Human Rights', European Journal of International Law, 25(4) (2015), 1019-1042; Buchanan, The Heart of Human Rights, 108. For an analysis of how such a 'learning process' can function internally within national law, see A. Sathanapally, Beyond Disagreement: Open Remedies in Human Rights Adjudication (Oxford: Oxford University Press, 2012), p. 63.
} 
(following Arendt) identifies this as an inherent 'paradox' that 'can never be fully resolved in democracies', but whose impact can be 'mitigated through the renegotiation and reiteration of the dual commitments to human rights and sovereign self-determination'. ${ }^{62}$ IHRC judgments contribute to this negotiation process by protecting non-nationals and other groups who tend to be marginalised within the functioning of national constitutional democratic systems - as evidenced by decisions such as, yes, Hirst $v$ UK (No 2). ${ }^{63}$

Thus, as Stephen Gardbaum has suggested, the influence exerted by IHRCs over the development of national law can help to 'advance the project of constitutionalism'. ${ }^{64}$ As a result, assertions that the authority of IHRCs is eroding popular sovereignty need to be balanced against the positive contribution they make to the development and maintenance of a healthy culture of democratic constitutionalism in the state concerned.

Fourthly, the impact of state disobedience on the authority of IHRCs needs also to be taken into account. When states refuse to abide by IHRC judgments, this weakens the status of these judgments and may encourage other states to follow suit. In turn, this can undermine the status of the relevant treaty instruments. It can also reduce the potential of IHRCs to act as a positive force in the development of democratic constitutionalism, both with respect to the specific state in question and also vis-à-vis other state parties coming under the same treaty framework.

This latter point is particularly significant. In deciding whether to disobey an IHRC judgment, states need to take account of what impact their disobedience will have on the overall functioning of the SIHRL framework in question - and on the inhabitants of other states, who may depend more on the IHRC in question to help secure their rights than do the inhabitants of the potentially disobeying state. ${ }^{65}$ Pinto-Duschinsky has dismissed this external dimension as irrelevant to the question of whether the authority of the Strasbourg Court is compatible with democratic self-governance: in his view, if deferring to the authority of the Strasbourg Court undermines democracy in the UK, then 'that is something too important and too intimate to be sacrificed for the supposed but unproven advantage of other peoples'. ${ }^{66}$ However, this argument is too simplistic. If you accept that democratic self-governance is desirable for your own country, then it is only logical that you should also be concerned with the health of democratic self-governance in other countries. It makes little sense to argue that the moral commitment to promote democracy should stop at, say, the English Channel. States may have

\footnotetext{
${ }^{62}$ S. Benhabib, Another Cosmopolitanism, (Oxford: Oxford University Press, 2008), p. 35.

${ }^{63}$ This function of SIHRL in general, and IHRCs in particular, lends support to Kumm's contention that 'any conception of national constitutionalism that takes as basic the idea of free and equals governing themselves is internally connected to a cosmopolitan paradigm of constitutionalism. It is ultimately not possible to make sense of the idea of constitutional self-government of free and equals within the statist paradigm.' See M. Kumm, 'The Cosmopolitan Turn in Constitutionalism: On the Relationship Between Constitutionalism in and Beyond the State', in J. L. Dunoff \& J. P. Trachtman (eds.), Ruling The World? Constitutionalism, International Law, and Global Governance (Cambridge: Cambridge University Press, 2009), p. 258-325, 315.

${ }^{64}$ S. Gardbaum, 'Human Rights and International Constitutionalism', in J. L. Dunoff \& J. P. Trachtman (eds.), Ruling The World? Constitutionalism, International Law, and Global Governance (Cambridge: Cambridge University Press, 2009), p. 254-55.

${ }^{65}$ Moravcsik has argued that the ECHR system has benefited the emerging democracies of southern and eastern Europe by enabling them to 'lock in' civil and political rights into their governance cultures, which in turn has helped to maintain the foundations of their nascent democratic systems through a period of constitutional turbulence. See A. Moravcsik, 'The Origins of Human Rights Regimes: Democratic Delegation in Postwar Europe', International Organisation, 54(2) (2000), 217-252.

66 M. Pinto-Duschinsky, Bring Rights Back Home: Making human rights compatible with parliamentary democracy in the UK, (London: Policy Exchange, 2011), p. 65.
} 
legitimate grounds to disobey an IHRC judgment, but in deciding to take that step they need to give due weight to the impact of their actions in the round.

These four factors taken together lend weight to the argument that states should be very slow to disobey IHRC judgments, or to denounce their treaty obligations, in this respect, in their entirety. These should remain 'nuclear options', to be invoked by national parliaments and other state actors only in exceptional circumstances - and states should have to bear a heavy burden of justification before they escape legal, political and diplomatic censure for failing to abide by their treaty commitments. ${ }^{67}$

Furthermore, the wriggle room that SIHRL gives to states when it comes to implementing IHRC judgments needs to be taken into account. When a state is the subject of a negative judgment, national authorities can delay and prevaricate for years before taking any action in response. They can also seek to convince the IHRC in question to change its mind or dilute its standards, while taking minimal steps to give effect to the initial negative judgment. ${ }^{68}$ As Bellamy notes, there is also a substantial political dimension to the process of enforcing IHRC judgments: states cannot usually be compelled to give effect to such judgments as a matter of national law, while the extent of diplomatic pressure brought to bear on a non-complying state may vary depending on how egregious their non-compliance is perceived to be. ${ }^{69}$

It appears therefore that there is little need to amend existing SIHLR instruments to introduce a 'democratic override' mechanism, or some sort of similar provision designed to allow states to reject IHRC judgments. Any such reform risks destabilising the already fragile equilibrium of these treaty systems, which in any case already allow states considerable room to push back against IHRC judgments to which they object. If national parliaments or other state organs wish to disobey an IHRC judgment, then they should do so within the confines of the existing SIHLR framework - and be required to satisfy the heavy burden of justification that such a step should entail.

\section{Conclusion}

Democratic constitutionalism is underpinned by a commitment to the idea that the authority of law-making institutions should be derived from the will of the people - or as Paul Kahn expresses it, 'the polity should express the rule of law'. ${ }^{70}$ IHRCs, as cosmopolitan courts embedded in a 'statist paradigm', are vulnerable to the allegation that their authority lacks a firm democratic basis. As such, national parliaments and other state organs may in certain circumstances be justified in refusing to give effect to IHRC judgments, in the interest of maintaining fidelity to the principle of popular sovereignty. However, this 'red line' should only be crossed in exceptional circumstances - and national authorities should have to bear a heavy burden of justification in this regard. National parliaments cannot simply disregard the system of rights protection established under the ECHR system between state parties to the ECHR and the individuals within their jurisdiction because they disapprove of a particular

\footnotetext{
${ }^{67}$ The authority of IHRCs could thus be viewed as having 'ecological legitimacy', to use Buchanan's phrase: i.e. their legitimacy derives in part from their functional relationship with other institutions and international actors. See Buchanan, The Heart of Human Rights, ch. 5.

${ }^{68}$ As discussed in the previous chapter, the Hirst saga in the UK illustrates this point.

${ }^{69}$ Bellamy, 'The Democratic Legitimacy of International Human Rights Conventions'.

${ }^{70}$ P. Kahn, 'Comparative Constitutionalism in a New Key', Michigan Law Review, 101(8) (2003), 2677-2707, 2677.
} 
judgment. ${ }^{71}$ Furthermore, no real justification exists for building some form of 'democratic override' into the framework of SIHRL.

${ }^{71}$ See the evidence given by Jeremy Waldron to the Joint Committee on Human Rights of the UK Parliament, Tuesday $15^{\text {th }}$ March 2011, HC 873-i, p. 51. 